\title{
Structure and Mechanical Properties of Aluminium Alloy Sampled from a Firefighter Ladder
}

Jiř́i Kubásek, Dalibor Vojtěch, Drahomír Dvorský

Department of Metals and Corrosion Engineering, University of Chemistry and Technology, Prague, Technická 5, 166 28 Prague 6, Czech Republic. E-mail: kubasekj@vscht.cz, vojtechd@vscht.cz

Firefighter ladders are manufactured of aluminium alloy AA 6063. These ladders are a widely used technical tool for firefighting, for intervening firefighters and for rescued persons. The quality of the ladders is checked by socalled "user test" which is a non-destructive deflection test defined by CSN EN 1147. Unfortunately, this test is not sufficiently conclusive in terms of safety. Therefore, the project called "Safety improvement of extension ladders for firefighters" (VI20162020021) is focused on the complex assessment of the existing firefighter ladders through mathematical modelling, material analysis and real testing. In the present work structure and mechanical properties of samples (aluminium alloy AA 6063) taken from different areas of a firefighter ladder are presented. The obtained result confirm excellent mechanical properties of selected samples, such as tensile yield strength and ultimate tensile strength, at laboratory temperature but a huge decrease in these properties after exposure to temperatures above $200^{\circ} \mathrm{C}$ for even short times. This results in the necessity to control temperatures in the proximity of the ladder, especially in the case when the ladder is located near a flame.

Keywords: Aluminium alloy 6063, firefighter ladder, Electron microscopy, Mechanical characterization

\section{Acknowledgement}

Authors wish to thank the Ministry of Interior (project: Safety improvement of extension ladders for firefighters VI20162020021) and specific university research (MSMT No 20-SVV/2017) for the financial support of this research.

\section{References}

[1] LUŠTINEC, J., OČENÁŠEK, V., JELÍNEK, M. (2016). Structure of Al-Mg-Si cast and extruded rods for die forgings. In: Manufacturing Technology, Vol. 16, No. 5, pp. 1009-1013.

[2] KOVALČÍK, T., STOULIL, J., SLÁMA, P., VOJTĚCH, D. (2015). The influence of heat treatment on mechanical and corrosion properties of wrought aluminium alloys 2024 and 6064. In: Manufacturing Technology, Vol. 15, No. 1, pp. 54-61.

[3] LOU, S., WANG, Y., LU, S., SU, C. (2016). Extrusion process parameters optimization for the aluminum profile extrusion of an upper beam on the train based on response surface methodology. In: Manufacturing Technology, Vol. 16, No. 3, pp. 551-557.

[4] SIDDIQUI, R. A., ABDULLAH, H. A., AL-BELUSHI, K. R. (2000). Influence of aging parameters on the mechanical properties of 6063 aluminium alloy. In: J Mater Process Tech, Vol. 102, No. 1, pp. 234-240.

[5] Aluminium Alloys - Aluminium 6063/6063A Properties, Fabrication and Applications. http://www.azom.com/article.aspx?ArticleID=2812\#2 (accessed 29.08.2017).

[6] Understanding Extruded Aluminium Alloys. https:/web.archive.org/web/20031006212043/http:/www.alcoa.com/adip/catalog/pdf/Extruded_Alloy_6063.pdf(accessed 28.08.2017).

[7] Alloy data sheet EN AW-6063 [AlMg0.7Si] http://www.nedal.com/wp-content/uploads/2016/11/Nedal-alloy-Datasheet-EN-AW-6063.pdf. (accessed 28.08.2017).

[8] AYDI, L., KHLIF, M., BRADAI, C., SPIGARELli, S., CABIBBO, M., MEHTEDI, M. E. (2015). Mechanical Properties and Microstructure of Primary and Secondary AA6063 Aluminum Alloy after Extrusion and T5 Heat Treatment. In: Materials Today: Proceedings, Vol. 2, No. 10, pp. 4890-4897.

[9] ASENSIO-LOZANO, J., SUÁREZ-PEÑA, B., VANDER VOORT, G. (2014). Effect of Processing Steps on the Mechanical Properties and Surface Appearance of 6063 Aluminium Extruded Products. In: Materials, Vol. 7, No. 6, pp. 4224.

[10] GAVGALI, M., TOTIK, Y., SADELER, R. (2003). The effects of artificial aging on wear properties of AA 6063 alloy. In: Materials Leters, Vol. 57, No. 24, pp. 3713-3721. 